Sains Peternakan Vol. 13 (1), Maret 2015: 22-35

ISSN 1693-8828

\title{
Pola Gender dalam Peternakan Babi Pada Peternak Etnis Arfak, Papua Barat
}

\author{
Deny A. Iyai ${ }^{1}$ dan Desni T.R. Saragih ${ }^{2}$ \\ ${ }^{1}$ Jurusan Produksi Ternak. Fakultas Peternakan. Papua University, Manokwari. Jl. Gunung Salju, \\ Amban. Manokwari. Postal code 98314. West New Guinea. Indonesia. \\ ${ }^{2}$ Jurusan Nutrisi dan Makanan Ternak. Fakultas Peternakan. Papua University, Manokwari. \\ E-mail:da.iyai@yahoo.com
}

\begin{abstract}
ABSTRAK
Penelitian bertujuan untuk mengkaji tentang peran wanita dan pria peternakan babi skala keluarga di etnis Arfak, Papua Barat. Penelitian dengan metode deskriptif dilaksanakan di Manokwari pada tiga kawasan agroekologi, pesisir, dataran rendah dan dataran tinggi. Penelitian melibatkan 22 orang kepala rumah tangga peternak berturut-turut sebanyak 10 orang, 7 orang dan 5 orang. Hasil penelitian menunjukkan bahwa tingkat produksi peternakan babi dari wanita Papua masih rendah dalam siklus agribisnis ternak babi dari tahapan pra produksi, namun meningkat perannya pada tahapan produksi sampai pasca-produksi. Peternak laki-laki masih dominan memiliki ternak namun pengambilan keputusan sudah dilakukan secara musyawarah dan demokratis. Tingkat pendapatan peternakan babi yang dipelihara oleh wanita dan pria berkisar dari Rp 2.000.000,00 sampai Rp 6.000.000,00.
\end{abstract}

Kata kunci: gender, agro-ekologi peternakan, pra-produksi, produksi, pasca produksi, Arfak.

\section{Gender Pattern in Pig Farming Systems of Arfak Ethnic, West Papua}

\begin{abstract}
The aim of this research was study of women and man concerning on pig family farming on Arfak ethnic, West Papua. Descriptive study was done in agro-ecological zones, i.e. coastal, lowland and highland. A 22 pig farmers were involved and interviewed subsequently, $10 \mathrm{hh}, 7 \mathrm{hh}$ and $5 \mathrm{hh}$. The finding of this research was that pig production level of the women was smaller than man in pre-production. Although increases in production level till pasca production. Man pig farmers were still dominant keeping the animals. However, decision was done democraticly. Level of income kept by women and men were in the ranges of Rp 2 million to Rp 6 million.
\end{abstract}

Keywords: gender, livestock agro-ecology, pre-production, production, pasca-production, Arfak.

\section{PENDAHULUAN}

Dilihat dari kondisi alam dan potensi sumber daya alam, Papua secara umum merupakan daerah yang sangat potensial bagi pengembangan peternakan. Beberapa komoditi ternak yang umumnya dipelihara di wilayah Papua adalah sapi, ayam, kambing dan ternak babi. Ternak babi adalah komoditas yang paling digemari bagi masyarakat Papua. Hal ini sejalan dengan budaya masyarakat Papua (Gobai, 2011). Populasi babi di Papua sendiri adalah sebesar 546.696 ekor. Jumlah ini berada pada rangking ke enam dari seluruh populasi babi di Indonesia (BPS, 2012).

Usahatani peternakan babi sebagai mata pencaharian andalan masyarakat Papua harus dikelola lebih intensif dalam skala rumah tangga. Kondisi peternakan babi saat 
ini di Papua masih berada pada tahapan yang subsisten (Awon, 2010; Iyai, 2008; Marani, 2004) yang juga menurut Soharto (1990) masuk dalam kategori usahatani tradisional. Usahatani ternak babi masih dilakukan secara sambilan dengan menggunakan tenaga kerja keluarga saja. Suratiyah (2007) mendefinsikan sistim ini sebagai family farming .

Menurut Mosse (2007) gender adalah seperangkat peran yang menyampaikan kepada orang lain bahwa kita adalah feminin atau maskulin. Lebih lanjut dijelaskan pula bahwa perangkat perilaku khusus yang mencakup penampilan, sikap, kepribadian, bekerja didalam maupun diluar rumah tangga dan tanggung jawab. Dengan demikian setiap wanita dan pria memiliki sifat atau kepribadian yang tidak bisa dibeda-bedakan karena perilaku gender berlaku pada jenis kelamin.

Pada kasus peternak babi di Papua, baik pria dan wanita sama-sama masuk dalam isu gender. Hal ini karena wanita dapat mengerjakan pekerjaan pria di luar dan dalam rumah. Sementara pria juga dapat melakukan pekerjaan pria di luar dan dalam rumah. Khusus peternakan babi, tahapan pekerjaan dimulai dari pra-produksi, produksi dan pasca produksi. Artikel ini bertujuan untuk mendiskusikan pola gender dalam aktifitas produksi peternakan babi pada etnis Arfak di Manokwari, propinsi Papua Barat.

\section{METODE PENELITIAN}

Penelitian kualitatif atau inkuiri alamiah (Moleong, 1991) telah dilaksanakan pada tanggal 2 Desember 2012 sampai dengan tanggal 4 Januari 2013. Beberapa distrik yang dikunjungi, dipilih dengan teknik purposif adalah Distrik Prafi, Distrik Warmare, Distrik Pantai Utara, Distrik Manokwari Barat dan Distrik Minyambouw. Kampung yang dikunjungi di pesisir adalah Warbefor, Meyes dan Saubeba. Ketinggian tempat kampungkampung ini adalah 15-30 mdpl. Udopi, Mepsi Umbui dan Sinamboy adalah kampung-kampung pada dataran rendah Prafi dan Warmare. Ketinggian kampung-kampung ini adalah 20-160 mdpl. Pada dataran tinggi kampung yang dikunjungi adalah kampung Handuk, Mtiede dan Mokwam. Ketinggian kampung ini adalah 1277-1488 mdpl.

Jumlah peternak yang terlibat, dipilih dengan menggunakan teknik sampling snowball (Nasir, 1999) sebanyak 22 orang kepala rumah tangga peternak. Metode deskriptif dengan teknik wawancara selama kurang lebih 45 menit data dikumpulkan (Koentjaraningrat, 1985). Rincian peternak 10, 7 dan 5 peternak yang masing-masing mewakili zona agroekologi berturut-turut kawasan pesisir, dataran rendah dan dataran tinggi Manokwari.

Deskripsi diri peternak yang meliputi jenis kelamin, umur (tahun), pengalaman (tahun), jumlah jiwa (orang), pendidikan dan kursus/pelatihan. Produksi ternak babi yang meliputi jumlah ternak babi (ekor), jumlah induk (ekor), litter size (/ekor/induk), litter sapih (ekor), jumlah induk jantan (ekor) dan cara memperoleh bibit. Pakan ternak babi meliputi sumber utama pakan, cara memperoleh pakan, harga pakan (Rp), pengolahan pakan, pemberian pakan dan sanitasi tempat pakan. Penjualan ternak babi meliputi jumlah yang dijual (ekor) dan harga yang dijual (Rp). Kesehatan Ternak meliputi ciri-ciri kesakitan yang dialami ternak. Peternakan babi pernah dikunjungi oleh mantri hewan dan penanganan ternak yang sedang sakit. Isu peternakan babi meliputi konstrain/hambatan dalam peternakan babi. Data dientri dalam Microsoft Excel 2010 dan dianalisis dengan menggunakan statistika deskriptif yang meliputi rataan, frekuensi dan persentase (Kasjono, 2010). 


\section{HASIL DAN PEMBAHASAN}

\section{Deskripsi Peternak}

\section{Jenis kelamin/Sex}

Peternak babi di Manokwari (Tabel 1)

masih didominasi oleh kaum laki-laki sebanyak 15 KK dan diikuti oleh kaum perempuan sebanyak $7 \mathrm{KK}$. Di pesisir komposisi/rasio peternak laki-laki perempuan adalah $2: 3$, di dataran rendah 4:3 dan dataran tinggi 5:0. Hal ini dilihat dari status kepala keluarga(KK).

Tabel 1. Deskripsi Peternak Babi.

\begin{tabular}{|c|c|c|c|c|c|c|}
\hline \multirow[b]{2}{*}{ Deskripsi Peternak } & \multicolumn{6}{|c|}{ Agroekologi } \\
\hline & $\begin{array}{l}\text { Pesisir } \\
(\mathrm{n}=10)\end{array}$ & $\begin{array}{l}\text { Proporsi } \\
(\%)\end{array}$ & $\begin{array}{c}\text { Dataran } \\
\text { rendah } \\
(\mathrm{n}=7)\end{array}$ & $\begin{array}{c}\text { Proporsi } \\
(\%)\end{array}$ & $\begin{array}{l}\text { Dataran Tinggi } \\
\quad(\mathrm{n}=5)\end{array}$ & $\begin{array}{l}\text { Proporsi } \\
\quad(\%)\end{array}$ \\
\hline Jenis Kelamin/Sex & & & & & & \\
\hline Laki/Man & 6 & 60 & 4 & 57 & 5 & 100 \\
\hline $\begin{array}{l}\text { Perempuan/Women } \\
\text { Etnis/Ethnicity }\end{array}$ & 4 & 40 & 3 & 43 & 0 & 0 \\
\hline Hatam & 2 & 20 & 2 & 29 & 5 & 100 \\
\hline Moskona & 3 & 30 & 1 & 13 & 0 & \\
\hline Sough & 2 & 20 & 2 & 29 & 0 & \\
\hline Miyah & 2 & 30 & 2 & 29 & 0 & \\
\hline Umur (th)/Ages (y) & 38 & & 40 & & 36 & \\
\hline $\begin{array}{l}\text { Pengalaman } \\
\text { (th)/Experiences (y) }\end{array}$ & 8.8 & & 9,1 & & 6,6 & \\
\hline $\begin{array}{l}\text { Jumlah jiwa/Hh no. } \\
\text { Pendidikan/Education }\end{array}$ & 4 & & 6 & & 4 & \\
\hline $\begin{array}{l}\text { Tidak sekolah } \\
\text { (Ayah/Ibu) }\end{array}$ & $3 / 5$ & $30 / 50$ & $4 / 5$ & $57 / 74$ & $1 / 4$ & $20 / 80$ \\
\hline SD(Ayah/Ibu) & $1 / 2$ & $10 / 20$ & $0 / 0$ & $0 / 0$ & $0 / 0$ & 0 \\
\hline SMP (Ayah/Ibu) & $2 / 2$ & $29 / 20$ & $1 / 1$ & $13 / 13$ & $0 / 1$ & 0 \\
\hline SMA (Ayah/Ibu) & $4 / 0$ & $40 / 0$ & $1 / 1$ & $13 / 13$ & $3 / 0$ & $60 / 0$ \\
\hline PT (Ayah/Ibu) & $0 / 1$ & $0 / 10$ & $1 / 0$ & $13 / 0$ & $1 / 0$ & $20 / 0$ \\
\hline $\begin{array}{l}\text { Pelatihan/Training } \\
\text { Pekeriaan }\end{array}$ & 1 & 10 & 0 & & 0 & \\
\hline $\begin{array}{l}\text { Pekerjaan } \\
\text { Tani+Ternak }\end{array}$ & 9 & 90 & 4 & 57 & 4 & 80 \\
\hline PNS+Tani+Ternak & 1 & 10 & 3 & 43 & 1 & 20 \\
\hline
\end{tabular}

Etnis Papua yang menjadi fokus dalam penelitian ini adalah Etnis Arfak, yang mendiami wilayah Pegunungan Arfak. Etnis ini terdiri atas empat sub-Etnis (klan), yakni
Hatam, Moskona, Sough dan Miyah. Dalam penelitian ini pengamatan terhadap responden dari ke-empat subetnis tersebut dibedakan berdasarkan tiga topografi, yakni dataran 
tinggi, dataran rendah dan pesisir. Di dataran tinggi, sebagian besar responden berasal dari subetnis Hatam dan Sough.

Etnis peternak yang ditemui sebanyak 4 Etnis yaitu Hatam, Sough, Miyah dan Moskona. Tidak ditemukan etnis Moile dari turunan suku besar Arfak. Marga dari etnis Hatam adalah Ullo, Muid, Ayok, Silabay, Wonggor dan Nuham. Marga peternak Etnis Miyah adalah Meidodga, Mandacan (bisa Sough dan Hatam) dan Bomoy. Sementara marga dari etnis Sough adalah Saiba dan Dowansiba. Marga dominan adalah dari etnis Hatam diikuti dengan Sough dan Miyah. Etnis Moskona adalah salah satu etnis Arfak yang berbatasan dengan etnis diantara ArfakManokwari dengan Arfak-Bintuni. Marga dari etnis ini adalah Oropcona.

Rataan umur peternak pada wilayah pesisir adalah 38 tahun, pada wilayah dataran rendah 40 tahun dan pada dataran tinggi adalah 36 tahun. Rataan umur peternak pada ke-3 lokasi ini masih berada pada kisarn umur produktif yaitu 15-55 tahun. Pengalaman peternak pada ke 3 lokasi agroekologi relatif tidak berbeda yaitu 8,8 tahun pada pesisir, 9,1 tahun pada dataran rendah dan pada dataran tinggi 6,6 tahun. Jumlah jiwa di dalam setiap rumah tangga adalah relatif seragam antara pesisir dan dataran tinggi, yaitu 4 orang/KK danpada dataran rendah adalah 6 orang/KK.

Tingkat pendidikan pada ketiga lokasi di dominasi oleh kelompok perempuan yang dikategorikan Tidak Sekolah dan relatif seragam pada ke 3 lokasi. Tamatan sekolah dasar pada wilayah pesisir sampai dengan wilayah dataran tinggi relatif masih tinggi. Sama halnya dengan tamatan SMP. Tamatan SMA didominasi oleh kaum laki-laki sementara perempuan dengan tamatan SMA tidak banyak ditemukan. Tamatan perguruan tinggi masih rendah ditemukan untuk ke dua jenis kelamin, baik laki-laki dan perempuan. Pelatihan masih sangat terbatas diikuti oleh peternak babi. Dari hasil interview, hanya terdapat 1 orang peternak yang pernah dilibatkan dalam pelatihan. Pekerjaan utama peternak masih didominasi oleh Tani dan Ternak. Pekerjaan sampingan seperti PNS masih terbatas. Pegawai Negeri Sipil yang ada di jajaran kampung/desa dijabat sebagai Kepala Kampung dan Sekretaris kampung. Dimana disela-sela pekerjaan sebagai PNS, pekerjaan utama mereka adalah sebagai petani dan peternak.

\section{Pembagian Tenaga Kerja}

\section{Pra-Produksi}

Pada tahapan pra-produksi (Gambar 1) kegiatan yang dilakukan meliputi 7 item yaitu pembukaan lahan kebun, beli bibit ternak, pembuatan kurungan, pembuatan kandang ternak, partisipasi dalam pelatihan, kepemilikan ternak babi dan pengaturan pembagian kerja. Pembukaan lahan adalah kegiatan fisik yang membutuhkan tenaga kerja besar. Lazimnya peternak dan petani Arfak melakukan pekerjaan ini oleh kaum laki-laki. Namun sekarang tidak menutup kemungkinan bahwa pekerjaan ini juga telah melibatkan wanita. Pembelian bibit ternak juga masih dilakukan oleh kaum lelaki. Namun kegiatan ini juga sudah ditoleransi oleh kaum wanita. Pembuatan kurungan untuk ternak babi adalah pekerjaan fisik yang dilakukan oleh kaum laki-laki dan sama halnya dengan pembuatan kadang ternak. Dalam hal partisipasi mengikuti pelatihan. Kaum laki-laki biasanya masih dominan ditemui pada suku Arfak dan perempuan jarang atau hampir tidak pernah mengikuti kursus atau pelatihan peternakan. Kepemilikan ternak babi sudah dilakukan secara demokrasi. Pembagian ternak babi dalam rumah tangga sudah mulai terbentuk diantara suku Arfak. Sementara pengaturan pembagian kerja kebanyakan dilakukan secara demokratis. Sedangkan hanya sebagian kecil saja ditemui pembagian kerja dilakukan oleh sang ayah.

Dari ke 7 item pra-produksi diatas dapat disimpulkan bahwa daerah Agroekologi Pesisir dan Dataran Tinggi masih didominasi 
oleh seorang Ayah, diikuti Ibu, anak laki-laki dan sebagian kecil oleh anak perempuan. Hal ini karena pekerjaan-pekerjaan dalam kegiatan pra-produksi masih merupakan jenis pekerjaan yang menjadi tanggung jawab ayah, yakni seperti pembukaan lahan, pencarian bibit, pembuatan kurungan/kandang ternak. Meskipun dalam pemeliharaan ternak babi, peran ibu cukup penting, namun dalam pekerjaan-pekerjaan yang memerlukan kekuatan fisik, peran ayah masih dominan. Keadaan ini berlaku di semua wilayah topografi. Demikian memperlihatkan bahwa, masyarakat Arfak masih memberi ruang kerja yang berbeda berdasarkan sifat-sifat gender. Menurut Mosse (2007) pria yang dianggap memiliki tenaga lebih besar, mengerjakan halhal yang diperlukan kekuatan fisik yang besardan perempuan yang secara fisiologis memiliki kekuatan yang atau tenaga yang relatif kecil, tidak diwajibkan atau diharuskan untuk bekerja pada pekerjaan yang memerlukan fisik yang besar. Selanjutnya dinyatakan pula dari sisi analisis gender aktifitas pra-produksi yang dilakukan oleh perempuan dengan terlibat juga sudah merupakan isu peran gender dalam pembangunan.

\section{Produksi}

Pada tahapan produksi kegiatan yang dilakukan meliputi 8 item yaitu pemberian makan, mandikan ternak, pembersihan kadang, pengaturan kawin, dipelihara di kebun, proses gestasi (partus), perawatan anak babi dan perawatan ternak babi yang sakit (Gambar 2).

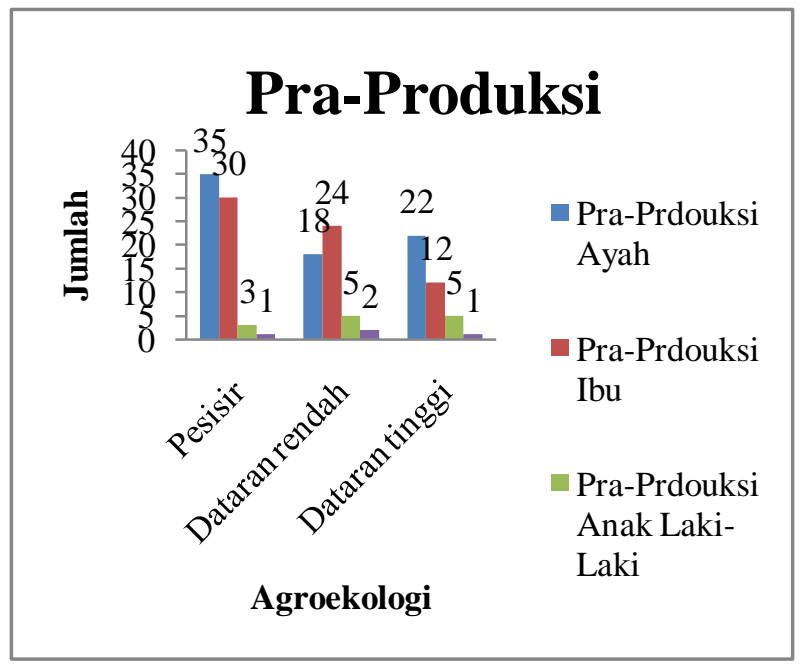

Gambar 1. Grafik kegiatan pra-produksi pada wilayah agoekologi.

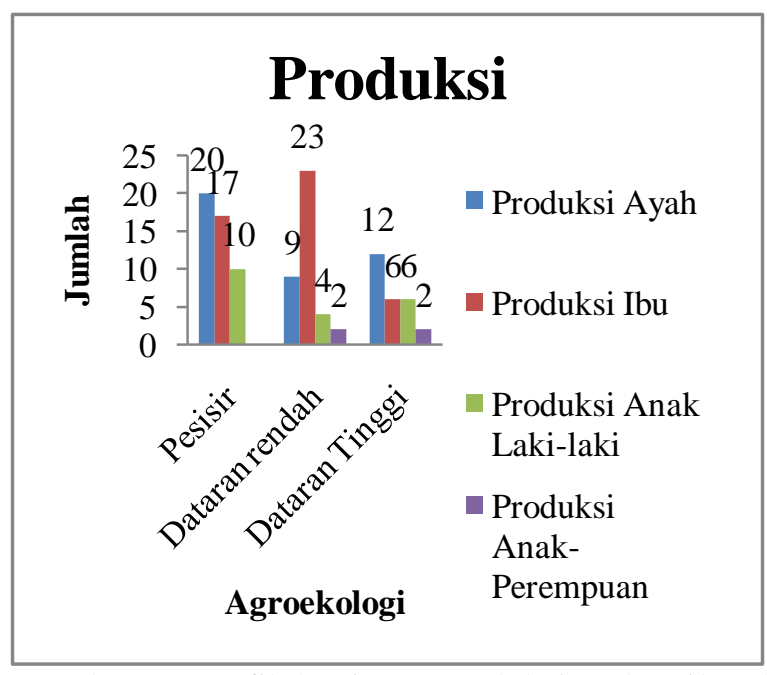

Gambar 2. Grafik kegiatan produksi pada wilayah agoekologi 


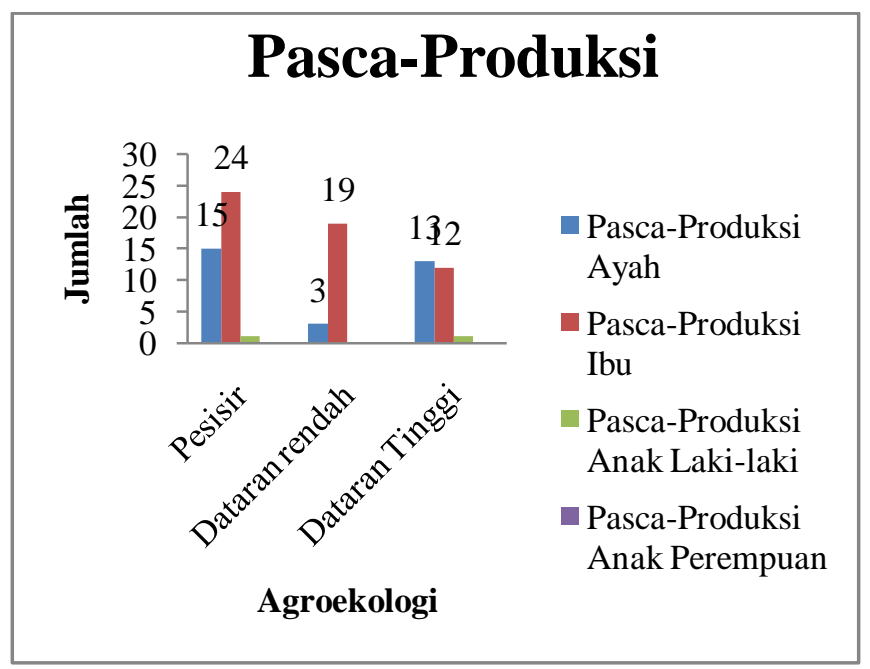

Gambar 3. Grafik kegiatan Pasca Produksi

Kegiatan agribisnis produksi dominan dilakukan oleh ibu pada dataran rendah diikuti oleh pesisir dan dataran tinggi. Umumnya keterlibatan ibu-ibu adalah pada proses pengumpulan bahan makanan dari kebun dan dan bekas lahan (crops and residues) serta dari sisa dapur (swill feed). Anak perempuan pula melakukan hal yang sama dengan ibu namun dalam jumlah yang sedikit. Hal ini dilakukan sebagai proses belajar yang dapat dilakukannya kelak setelah berumah tangga lagi. Menurut Suratiyah (2008) usahatani yang dilakukan oleh peternak etnis Arfak pada kawasan ini dominan bersifat usahatani campuran atau mixed farming.

Pengamatan dalam pekerjaan produksi terdapat perbedaan di antara ketiga topografi menyangkut pembagian peran. Daerah di dataran rendah pekerjaan produksi didominasi oleh ibu atau perempuan. Daerah di pesisir dan di dataran tinggi, pekerjaan produksi ini masih lebih banyak dilakukan oleh kaum bapak (pria), meskipun untuk pesisir perbedaan tersebut tidak begitu signifikan. Daerah di dataran rendah, kaum ibu lebih banyak sebagai obyek curahan waktu dalam mengurus ternak babi, karena kaum bapak sudah memiliki pekerjaan tetap, misalnya sebagai guru atau pegawai negeri. Dengan demikian ibu akan lebih banyak waktunya untuk mengurus kebun dan memelihara ternak babi. Hampir di semua wilayah topografi, pola pemeliharaan pada ternak babi memiliki kemiripan, yakni ternak dipelihara tanpa dikandangkan. Pada saat pagi hari sebelum ibu pergi ke kebun, terlebih dahulu memberi makan kepada ternaknya. Setelah itu ibu ke kebun untuk mencari makanan untuk ternak. Sementara ibu ke kebun, ternak babi juga berkeliaran di hutan-hutan di sekitar pemukiman. Ternak-ternak akan kembali lagi menjelang malam, saat ibu juga telah tiba dari kebun, sehingga ibu akan memberi makan sekali lagi kepada ternak.

Bagi masyarakat Arfak yang bermukim di dataran rendah, ibu yang memiliki waktu lebih banyak di kebun dan di rumah. Oleh karena itu, konsekuensi logisnya, ibu lebih bertanggung jawab dalam mengurus ternak babi dan kebun. Meskipun pada saatsaat tertentu ketika ibu membawa hasil kebun ke pasar, bapak akan mengambil tugas-tugas pemeliharaan ternak babi. Secara umum, sekalipun terlihat ada pembagian tugas antara ayah dan ibu dalam memelihara ternak babi, tetapi sesungguhnya pembagian tugas itu 
tıdak begitu melekat dengan posisi gender. Sebab sebagian besar responden menjelaskan bahwa dalam menjalankan kerja pemeliharaan ternak, lebih bergantung siapa yang sedang memiliki waktu. Jadi bilamana ibu sedang melakukan tugas-tugas lain di luar rumah, bapak sudah siap melaksanakan tugas pemeliharaan ternak, seperti mencari atau memberi makan kepada ternak. Di daerah pesisir terlihat bahwa gender pria (bapak) masih lebih tinggi dalam memelihara ternak babi, karena kaum ibu sebagian besar membawa hasil kebun ke pasar. Selama ibu di pasar, kaum bapak yang bertanggung jawab mengurus ternak babi.

\section{Pasca Produksi}

Pada kegiatan Pasca Produksi aktifitas yang dilakukan adalah keputusan konsumsi daging babi, keputusan menjual dan keputusan memberikan harga pada komoditi ternak babi. Kegiatan pasca produksi dominan dilakukan oleh kaum ibu pada semua kawasan agroekologi. Selain itu sharing dalam jumlah yang sedikit dilakukan juga oleh ayah seperti dalam hal pemotongan ternak untuk konsumsi, dan penjualan ternak. Penentuan harga ternak masih didominasi oleh ibu-ibu dan dalam jumlah kecil dilakukan dengan cara musyawarah (Demokrasi). Hal tersebut sesuai dengan pendapat Suratiyah (2006) bahwa model perencaan usahatahi ini disebut dengan self-determined.

Hampir sejalan dengan kegiatan produksi, yang mana mulai terlihat peran ibu, maka pada pasca produksi peran ini makin terlihat nyata (Gambar 3). Bagi masyarakat Arfak, urusan perekonomian dan manajemen rumah tangga lebih didominasi oleh pihak ibu (mama). Oleh karena itu saat ternak babi akan dijual, maka ibu memiliki keputusan penting untuk memberi persetujuan apakah ternak babi sudah boleh dijual dan pada harga berapa. Apabila belum ada persetujuan dari ibu, maka sang ayah tidak dapat menggunakan otoritasnya sebagai kepala rumah tangga untuk mengambil keputusan ternak babi dapat dijual. Keadaan ini menunjukkan bahwa dalam masyarakat Arfak, terdapat nilai-nilai demokrasi yang berkembang baik. Pemberian ruang kepada ibu untuk membuat keputusan dalam pasca produksi, menunjukkan bahwa sesungguhnya dalam masyarakat Arfak terdapat nilai-nilai yang memberi penghargaan kepada kaum perempuan, sebagaimana dengan peran dan tugasnya dalam pascaproduksi pemeliharaan ternak babi. Dengan demikian penelitian ini mendukung kesimpulan Mosse (2007) bahwa peran ini dipengaruhi oleh kelas, sosial, usia dan latar belakang etnis. Dengan demikian kerja perempuan dikenal dengan tiga serangkai yaitu reproduktif, ekonomi produktif dan manajemen komunitas.

\section{Produksi Ternak Babi}

Jumlah ternak babi yang dimiliki oleh peternak adalah relatif beragam. Pada daerah pesisir rataan jumlah ternak yang dapat dipelihara adalah 4-5 ekor, pada dataran rendah 6 ekor dan pada daerah dataran tinggi 10 ekor (Tabel 2). 
Tabel 2. Produksi Ternak Babi di Lokasi Contoh

\begin{tabular}{|c|c|c|c|c|c|c|}
\hline \multirow[b]{2}{*}{ Produksi ternak babi } & \multicolumn{6}{|c|}{ Agroekologi } \\
\hline & $\begin{array}{l}\text { Pesisir } \\
(\mathrm{n}=10)\end{array}$ & $\begin{array}{l}\text { Proporsi } \\
(\%)\end{array}$ & $\begin{array}{c}\text { Dataran } \\
\text { rendah } \\
(\mathrm{n}=7)\end{array}$ & $\begin{array}{c}\text { Proporsi } \\
(\%)\end{array}$ & $\begin{array}{l}\text { Dataran tingi } \\
\quad(\mathrm{n}=5)\end{array}$ & $\begin{array}{l}\text { Proporsi } \\
(\%)\end{array}$ \\
\hline $\begin{array}{l}\text { Jumlah ternak babi } \\
\text { (ekor)/Population }\end{array}$ & 4.7 & & 6.0 & & 10.0 & \\
\hline $\begin{array}{l}\text { Jumlah induk/ Herd } \\
\text { size }\end{array}$ & 2 & & 2 & & 2 & \\
\hline $\begin{array}{l}\text { Kelahiran } \\
\text { (th)/Farrowing }\end{array}$ & 1 & & 3 & & 2 & \\
\hline $\begin{array}{l}\text { Jumlah anak } \\
\text { babi/Litter size }\end{array}$ & 2 & & 6 & & 5 & \\
\hline $\begin{array}{l}\text { Jumlah induk jantan } \\
\text { Sumber bibit }\end{array}$ & 1 & & 0 & & 0 & \\
\hline Pemberian & 4 & 40 & 4 & 57 & 3 & 60 \\
\hline Harta Kawin & 0 & & 1 & 14 & 0 & \\
\hline Beli & 6 & 60 & 2 & 29 & 2 & 40 \\
\hline Kandang & 4 & 40 & 1 & 14 & 2 & 40 \\
\hline Tanpa Kandang & 6 & 60 & 6 & 86 & 3 & 60 \\
\hline
\end{tabular}

Jumlah induk betina yang dipelihara adalah satu ekor pada wilayah pesisir, diikuti oleh dataran tinggi sebanyak dua ekor dan pada dataran rendah sebanyak tiga ekor. Jumlah kelahiran per tahun (farrowing rate) adalah masih didominasi juga pada kawasan dataran rendah sebanyak tiga kali/tahun. Pada wilayah pesisir hanya sebanyak satu kali dan pada wilayah dataran tinggi hanya sebanyak dua kali. Hal ini menjadi penting diketahui bahwa ternak babi dapat beranak sebanyak tiga kali per tahun. Litter size ternak babi cukup rendah di daerah pesisir. Sementara daerah dataran rendah dan tinggi sudah cukup baik yaitu diatas 5-6 ekor per kelahiran. Hal ini sudah sesuai dengan hasil penelitian Iyai (2008) di lembah Prafi dan Warmare.

\section{Peta Sistim Peternakan Babi di Wilayah Agroekologi Manokwari}

Sistim peternakan babi di Manokwari berdasarkan profil agroekologi adalah sistim ekstensif yang dilakukan dengan cara diumbar pada lahan bekas kebun dan halaman rumah (backyard). Sistim intensif dominan dilakukan pada peternak di pesisir pada kampung Saubeba. Hal ini sudah diterapkan karena ada peraturan kampung yang telah disepakati bersama. Jika dilanggar maka peternak akan dikenakan sangksi berupa denda pembayaran ganti rugi sebesar Rp 1.500.000,00. Menurut Iyai (2008) sistim semi intensif dengan disediakannya kandang namun aktifitas basal ternak tidak dilakukan sepenuhnya dalam kandang dan sesekali dilepaskan pada waktu siang hari untuk membantu ternak sendiri mencari pakan sisa dan aktifitas reproduksi. Selain itu sistim intensif yang dilakukan dengan dikandangkannya ternak babi sepanjang hidupnya. 


\section{Pakan Ternak Babi}

Pada Tabel 3 berikut terlihat bahwa sumber pakan untuk ternak babi lebih banyak berasal dari tiga sumber yaitu kebun, lahan bekas dan sisa-sisa dapur (16 responden) untuk daerah pesisir dataran rendah maupun dataran tinggi dan 6 responden lainnya menyatakan bahwa pakan yang diperoleh hanya dari hasil kebun saja. Beberapa penelitian menunjukkan bahwa sumber pakan ternak babi bersumber dari kebun, lahan bekas dan sisa-sisa dapur (Awon, 2010; Yafur, 2008) baik pada dataran rendah dan tinggi (Iyai, 2008).

Pakan yang diperoleh ternak babi tergantung dari ketersediaan lahan atau kebun-kebun yang ditanami. Ternak babi pada pagi hari akan mencari pakan di kebun-kebun penduduk ataupun di lahan-lahan yang memungkinkan untuk mendapatkan pakan, kemudian pada sore hari babi babi tersebut akan pulang ke rumah pemeliharanya. Saat pulang ke tempat pemeliharanya tersebut, ada peternak yang memberi pakan pada babi peliharaannya (sore hari). Selain itu juga ada peternak yang memberikan pakan pada pagi hari saat sebelum ternak tersebut mencari pakan di lahan-lahan yang jauh dari sekitar tempat tinggal peternak. Hal ini sesuai dengan penelitian Iyai (2005) dan Warastuti (2001) pakan yang diperoleh untuk ternak babi hanya dari hasil kebun saja.

Tabel 3. Pakan Ternak Babi di Lokasi Contoh

\begin{tabular}{|c|c|c|c|c|c|c|}
\hline \multirow[b]{2}{*}{ Pakan ternak babi } & \multicolumn{6}{|c|}{ Agroekologi } \\
\hline & $\begin{array}{l}\text { Pesisir } \\
(\mathrm{n}=10)\end{array}$ & $\begin{array}{l}\text { Proporsi } \\
\quad(\%)\end{array}$ & $\begin{array}{c}\text { Dataran } \\
\text { rendah } \\
(\mathrm{n}=7)\end{array}$ & $\begin{array}{l}\text { Proporsi } \\
(\%)\end{array}$ & $\begin{array}{l}\text { Dataran Tingi } \\
\quad(\mathrm{n}=5)\end{array}$ & $\begin{array}{l}\text { Proporsi } \\
(\%)\end{array}$ \\
\hline Sumber pakan & & & & & & \\
\hline Kebun & 4 & 40 & 0 & 0 & 2 & 40 \\
\hline Kebun+lahan & 6 & 60 & 7 & 100 & 3 & 60 \\
\hline Bekas+sisa dapur & & & & & & \\
\hline $\begin{array}{l}\text { Harga pakan/bln } \\
\text { (Rp) }\end{array}$ & 15.000 & & 57.000 & & 12.000 & \\
\hline Olah pakan & & & & & & \\
\hline $\begin{array}{l}\text { Masak/Tanpa } \\
\text { Masak }\end{array}$ & 10 & 100 & 7 & 100 & 5 & 100 \\
\hline $\begin{array}{l}\text { Frekuensi pakan } \\
\text { (kali) }\end{array}$ & 1 & & 2 & & 1 & \\
\hline Satu kali & 8 & 80 & 4 & 60 & 4 & 80 \\
\hline Dua kali & 2 & 20 & 3 & 40 & 1 & 20 \\
\hline
\end{tabular}

Pada saat ternak mencari pakan sendiri, pakan yang dikonsumsi adalah jenisjenis tanaman apa saja yang diperoleh di sekitar tempat umbaran. Selain itu, pakan ternak babi yang diberikan berasal dari hasil kebun milik peternak yang dipanen bersamaan 
dengan bahan-bahan yang akan dikonsumsi maupun bahan-bahan yang akan siap dijual ke pasar, diantaranya ubi kayu, ubi jalar, keladi dan labu siam. Bila dilihat dari jenis pakan yang dikonsumsi ternyata dominan berupa pakan sumber karbohidrat (ubi kayu, ubi jalar, keladi). Bila dilihat dari fungsinya, karbohidrat ini diperlukan sebagai sumber energi yang mampu mempertahankan panas tubuh maupun aktivitasnya. Namun keseimbangan antara sumber energi dengan sumber gizi lainnya tidak terwujud dengan baik seperti bahan pakan sumber protein. Padahal, protein sangat dibutuhkan untuk pertumbuhan anak-anak babi dan ternak fase grower.

Pengolahan bahan makanan ternak babi yang dilakukan peternak yaitu dimasak dan tanpa dimasak (mentah). Pengolahan tanpa dimasak pada umumnya sangat mudah dilakukan, karena diberikan dalam bentuk segar meskipun dicacah terlebih dahulu. Pengolahan dengan cara dimasak akan membutuhkan waktu yang cukup, karena selain dikupas terlebih dahulu, dicampur dengan air dan juga harus dididihkan kurang lebih 30 menit sambil diaduk-aduk supaya campuran masak merata.

\section{Penjualan Ternak Babi}

Penjualan ternak babi masih rendah dan bersifat aksidental, jika ada permintaan. Akses masyarakat dengan pasar dinilai masih terbatas. Rataan jumlah ternak yang dijual adalah dua ekor di wilayah pesisir, satu ekor di dataran rendah dan dua ekor di dataran tinggi (Tabel 4). Harga jual ternak babi relatif tinggi di wilayah pesisir yaitu $\mathrm{Rp}$ 6.500.000,00, sedangkan di dataran rendah yang bersumber dari ternak babi sebesar $\mathrm{Rp}$ 2.250.000,00 dan di dataran tinggi Minyambouw sebesar Rp 6.000.000,00 juta. Sumbangan pendapat terbesar pada daerah dataran rendah Prafi dan Warmare bagi masyarakat Arfak adalah ternak sapi dan hasil kebun.

Tabel 4. Penjualan Ternak Babi di Lokasi Contoh

\begin{tabular}{|c|c|c|c|c|c|c|}
\hline \multirow[b]{2}{*}{$\begin{array}{l}\text { Penjualan ternak } \\
\text { babi }\end{array}$} & \multicolumn{6}{|c|}{ Agroekologi } \\
\hline & $\begin{array}{l}\text { Pesisir } \\
(\mathrm{n}=10)\end{array}$ & $\begin{array}{l}\text { Proporsi } \\
(\%)\end{array}$ & $\begin{array}{l}\text { Dataran rendah } \\
\qquad(\mathrm{n}=7)\end{array}$ & $\begin{array}{l}\text { Proporsi } \\
(\%)\end{array}$ & $\begin{array}{c}\text { Dataran } \\
\text { Tingi } \\
(\mathrm{n}=5)\end{array}$ & $\begin{array}{l}\text { Proporsi } \\
(\%)\end{array}$ \\
\hline Jumlah jual (ekor) & 2 & & 1 & & 2 & \\
\hline Harga jual (Rp.000) & 6.500 & & 2.250 & & 6.000 & \\
\hline Keputusan jual & & & & & & \\
\hline Ayah & 2 & 20 & 1 & 20 & 1 & 20 \\
\hline $\mathrm{Ibu}$ & 6 & 60 & 6 & 80 & 1 & 20 \\
\hline $\begin{array}{l}\text { Musyawarah } \\
\text { (Ayah+Ibu) } \\
\text { Keputusan } \\
\text { konsumsi }\end{array}$ & 2 & 20 & 0 & & 3 & 60 \\
\hline Ayah & 2 & 20 & 1 & 10 & 1 & 20 \\
\hline Ibu & 5 & 50 & 4 & 60 & 1 & 20 \\
\hline $\begin{array}{l}\text { Musyawarah } \\
\text { (Ayah+Ibu) }\end{array}$ & 3 & 30 & 2 & 30 & 3 & 60 \\
\hline
\end{tabular}


Sama halnya dengan peternak babi di wilayah pesisir dan dataran tinggi yang bersumber dari hasil kebun. Soekartawi (2003) menyebutkan ini sebagai "stars problem" karena produk yang dipasarkan adalah paling menguntungkan dan karenanya pengembangan produk tersebut perlu mendapatkan prioritas. Keputusan konsumsi hasil peternakan yang ditentukan oleh ibu adalah di wilayah pesisir dan dataran rendah. Dilanjutkan dengan keputusan konsumsi secara musyawarah (ayah+ibu) pada pesisir dan dataran tinggi.

\section{KESIMPULAN}

1. Tingkat produksi peternakan babi dari wanita Papua masih rendah dalam siklus agribisnis ternak babi dari tahapan pra produksi, namun meningkat perannya pada tahapan produksi sampai pasca-produksi. Peternak laki-laki masih dominan memiliki ternak namun pengambilan keputusan sudah dilakukan secara musyawarah dan demokratis.

2. Tingkat pendapatan peternakan babi yang dipelihara oleh wanita dan pria berkisar dari Rp 2.000.000,00-Rp 6.000.000,00 dan faktor-faktor yang menentukan dinamika pendapatan adalah harta kawin, kematian serta hilangnya ternak karena masalah sosial.

\section{UCAPAN TERIMAKASIH}

Penulis mengucapkan terimakasih kepada Direktur JiKTI di Makassar, Sulawesi Selatan atas grant penelitian yang diberikan pada tahun 2012. Kepada para peternakan babi di Manokwari, penghargaan yang setinggi-tingginya disampaikan atas kerjasamanya selama ini.

\section{DAFTAR PUSTAKA}

Anonimous. 2011. Geografi Indonesia, kabupaten di Indonesia.
http://id.wikipedia.org/wikiKabupaten _Jayawijaya. Diakses 25 September 2011.

Basna, A. 2010. Karakteristik Morfometri Ternak Babi Lokal (Sus sp.) pada Sistim Pemeliharaan Diumbar dibawah Naungan Kelapa Sawit dan dikandangkan di Lembah Prafi Kabupaten Manokwari. Laporan penelitian. Fakultas Peternakan Perikanan dan Ilmu Kelautan Universitas Negeri Papua. Manokwari.

BPS Papua Barat. 2005. Papua Barat dalam Angka.

BPS Indonesia. 2010. Indonesia dalam Angka. Dwiyatmo, K.B. 2006. Kiat Menjadi Petani Sukses. Citra Adi Parama. Yogyakarta.

Ferdinand, A. 2006. Sructural Equation Modeling dalam Pelitian Manajemen. BP UNDIP. Semarang.

FIA. 2005. Collaborative Efforts between Food Security Council and the United Nation Wolrd Food Programme (WPFFAO). Jakarta.

Ghozali, I. 2008. Model Persamaan Struktural: Konsep dan Aplikasi dengan Program Amos 16. BP UNDIP. Semarang.

Gobay, B. 2011. Hubungan Antara Motif Ekonomi dan Motif Sosial terhadap Perkembangan Ternak Babi pada Masyarakat Suku Arfak di Manokwari. Laporan Penelitian. Fakultas Peternakan Perikanan dan Ilmu Kelautan. Universitas Negeri Papua. Manokwari.

Iyai, D.A. 2008. Inovation of Pig Keeping System in Pig Farmers at Manokwari, West Papua Province, Indonesia. Tesis Wegeningen University. The Netherlands.

Iyai, D.A., D. Woran and I. Sumpe. 2010. Clustering and principal component analyses of constraints in smallholding pig keeping systems in Manokwari, Indoensia. Journal of Animal Production. 12(3): 199-206. 
Iyai, D.A., B.W.I. Rahayu, I. Sumpe, D. Saragih. 2011. Analysis of pig profiles on small-scale pig farmers in Manokwari-Papua Barat. Journal Indonesian-Animal. Agriculture.36(3): 190-198.

Kasjono, H.S. 2010. Cara Praktis Memahami Biostatistik. Gosyen Publishing. Yogyakarta.

Katagame, A. 2012. Teknik Budidaya Ternak Babi oleh Suku Amungme dan Dani di Puncak Jaya. Laporan Penelitian. Fakultas Peternakan Perikanan dan Ilmu Kelautan Universitas Negeri Papua. Manokwari.

Khomsam, A. 1999. Fenomena Kemiskinan. Harian Suara Pembaharuan, 1 Nopember 1999. http://www.indonews.com/, Jakarta.

Rusastra, I.W. dan Sudaryanto, T., 2006. Kebijakan strategi usaha pertanian dalam rangka peningkatan produksi dan pengentasan kemiskinan. Jurnal Litbang Pertanian. 25(4).

Ilham, N. dan B.M. Sinaga. 2007. Penggunaan pangsa pengeluaran pangan sebagai indikator komposit ketahanan pangan. SOCA Jurnal Sosial Ekonomi Pertanian dan Agribisnis.7(3): 213328.

Kuntjaraningrat. 1985. Metode-metode Penelitian Masyarakat. Gramedia. Jakarta.

Marani, O.Y. 2004. Pemeliharaan Ternak Babi oleh Masyarakat Suku Arfak di Kampung Gaya Baru Kelurahan Wosi Distrik Manokwari. Laporan Penelitian. Fakultas Peternakan Perikanan dan Ilmu Kelautan Universitas Negeri Papua. Manokwari.

Marjen, T.F. 2007. Pola Pemberian dan Jenis Pakan yang diberikan pada Ternak Babi oleh Masyarakat di Distrik Samofa Kabupaten Biak Numfor. Laporan Penelitian. Fakultas Peternakan Perikanan dan Ilmu
Kelautan. Universitas Negeri Papua. Manokwari.

Maxwell, S. and T. Frankerberger. 1992. Household Food Security: Concepts Indicator, Measurements; A Technical Review. UNICEF and IFAD, New York and Rome.

Moleong, L.J. 1991. Metodologi Penelitian kualitatif.Penerbit. PT. Remaja Rosdakarya. Bandung.

Mosse, J.C. 2007. Gender dan Pembangun. Penerbit Rifka Annisa Crisis Centre dengan Pustaka Belajar. Yogyakarta.

Mubyarto. 1994. Pengantar Ekonomi Pertanian. LP3ES. Jakarta.

Mulyadi, 2012. Budaya Pertanian Papua: Perubahan Soaial dan Strategi Pemberdayaan Masyarakat Arfak. Kartamedia Bantul. Yogyakarta.

Nasir, M. 1988. Metode penelitian. Cetakan ke 3. Penerbit Ghalia. Jakarta. Indonesia.

Pattiselano, F. dan D.A. Iyai. 2005. Peternakan Babi di Manokwari Mempertahankan Tradisi dan Meningkatkan Taraf Hidup.

Pattiselano, F. 2005. Limbah yang berguna: Harapan peternak babi terhadap sumber pakan alternatif di pesisir Manokwari. Majalah Pertanian Berkelanjutan SALAM. No. 13(2005): 24-25.

Piters, P. 2001. Local human-sweet potato-pig systems: Characterization and research in Irian Jaya, Indonesia with limited reference to Papua New Guinea. A $2^{\text {nd }}$ literature review. In: Poverty Alleviation and Food Security through improving the Sweet potatoes-Pig Systems in Indonesia and Vietnam"International Potato Center (CIP).

Prayitno, H. dan L. Arsyad. 1997. Petani desa dan kemiskinan. BPFE. Yogyakarta.

Randa, S.Y. 1994. Performance of indigenous pigs of upland and lowland Irian Jaya. 
Thesis. Department of Animal Science. Los Banos, The Philippines.

Rahardi, F. dan R. Hartono. 2003. Agribisnis

Peternakan. Penebat Swadaya, Jakarta.

Rahayu, B.W.I. 2011. Penampilan Dua

Genetik Babi Pada pemeliharaan

Intensif di kota Manokwari. Laporan

Penelitian FPPK. Unipa.

Rahayu, B.W.I., I.U. Warsono dan B. Abner.

2011. Pengembangan Babi Lokal dilahan kelapa Sawit (Palm-Pig) untuk menunjang Ketahanan Pangan Spesifik Lokal Papua. Dalam: Proseding Seminar Nasional Fakultas Peternakan Universitas Jenderal Sudirman: Prospek dan Potensi Sumber daya Peternakan Lokal dalam Menunjang Ketahanan Pangan Hewani.

Rahayu, B.W.I., D. Nurhayati, dan I. Sumpe.

2011. Pemanfaatan Limbah Buah

Merah (Pandanus Conoideus Lam) dalam Meningkatkan Pertumbuhan dan Status Kesehatan Babi di Kampung Umpakalo Kabupaten Jaya Wijaya. Laporan Penelitian. Fakultas Peternakan Perikanan dan Ilmu Kelautan. Universitas Negeri Papua.

Ropa, M. 2001. Sistim Pemberian Pakan pada Usaha Peternakan Babi Rakyat di Kecamatan Manokwari. Laporan Penelitian. Fakultas Pertanian. Universitas Cenderawasih.

Salabai, B. 2009. Babi Perdamaian Penginjilan Kontekstual Suku Arfak. Penerbit Theresia Yogyakarta.

Santosa, S. 2007. Sructural Equation Modelling, Konsep dan Aplikasi dengan AMOS. Elex Media Komputindo. Kelompok Gramedia. Jakarta.

Sayogyo. 1986. Garis Kemiskinan dan

Ukuran Tingkat Kesejahteraan

Penduduk. Tidak diterbitkan.

Simanungkalit, D. 2001. Performans Reproduksi Ternak Babi (Sus sp.) di Kecamatan Kebar Kabupaten Manokwari. Skripsi. Fakultas
Pertanian Universitas Cenderawasih. Manokwari.

Soekartawi, A. Suharjo, John L. Dillon dan J. Brian Hardaker. 1986. Ilmu usahatani dan penelitian untuk pengembangan petani kecil. Universitas Indonesia Press. Jakarta.

Suebu, B. 2007. Masa Depan Pembangunan Pertanian di Papua: Peluang dan Tantangan. Orasi ilmiah pada Rapat Terbuka Senat UNIPA. Wisuda Sarjana dan Diploma. Universitas Negeri Papua. Manokwari.

Supardi. 2002. Analisis ekonomi rumah tangga di pedesaan miskin pinggiran hutan Kabuopaten Grobogan. Disertasi. Universitas Gadjah Mada. Yogyakarta.

Suratiyah, K. 2008. Ilmu Usahatani. Penebar Swadaya. Jakarta.

Pusat Penelitian dan Pengembangan Sosial Ekonomi Pertanian. 2010. Ketersediaan Beras Nasional dan Ketahanan Pangan. ICASERD WORKING PAPER No. 3. http://www.deptan.co.id

Usior, L.F. 2008. Sistim Pemeliharaan Ternak Babi Peserta Bantuan Pinjaman Langsung masyarakat (BPLM) Di Kampung Yapen. Laporan Penelitian. Fakultas Peternakan Perikanan dan Ilmu Kelautan. Universitas Negeri Papua. Manokwari.

Warastuti, D.F. 2001. Sistim Pemeliharaan Ternak Babi di Pesisir Teluk Doreri Kabupaten Manokwari. Skripsi. Fakultas Peternakan Perikanan dan Ilmu Kelautan. Universitas Negeri Papua. Manokwari.

Wonatorei, M. 2009. Persepsi peternak babi terhadap penertiban hewan/ternak peliharaan (Studi kasus SK. Bupati Manokwari No. 357 Tahun 2004). Laporan Penelitian. Fakultas Peternakan Perikanan dan Ilmu Kelautan. Universitas Negeri Papua. Manokwari. 
Woran J. dan L. Sonbait. 2008. Monitoring dan evaluasi pembangunan peternakan provinsi Papua. Laporan Penelitian. Kerjasama Dinas Peternakan Provinsi Papua dan Fakultas Peternakan Perikanan dan Ilmu Kelautan. Universitas Negeri Papua. 